$\mathbb{T}$ periodica polytechnica

\author{
Social and Management Sciences \\ $21 / 1(2013) 3944$ \\ doi: $10.3311 /$ PPso. 2155 \\ http://periodicapolytechnica.org/so \\ Creative Commons Attribution (1)
}

RESEARCH ARTICLE

\section{How to increase workplace commitment?}

\author{
Zoltán Krajcsák / Irén Gyökér
}

Received 2013-01-10

\section{Abstract}

The improvement of individual performance essentially depends on management of human resources and motivation of employees. The key to mobilizing intrinsic driving force is commitment. Its development, alongside the increase of employee satisfaction which is the foundation of commitment, has become the centre of attention of theoretical experts and practicing managers in recent years. Not even during periods of economic crisis can companies afford to cut down investments into or put less emphasis on the improvement of human resources. Managers have to realize that labor costs are on the rise whereas employee commitment shows an inevitable decline due to different factors over time. Therefore they need to make a continuous effort to understand how commitment is created, which factors do influence it in order to ensure that the source of the organizations distinctive power and competitiveness alongside the value creating ability of human capital leads to desired business outcomes.

In this article we are going to introduce and compare the different interpretations of commitment, and define its relationship to motivation and explain the evolution of commitment models with the intention to highlight the concept of commitment. Also, we will analyze the methods of improving commitment.

\section{Keywords}

commitment $\cdot$ satisfaction $\cdot$ motivation $\cdot$ social exchange theory $\cdot$ perceived organizational support $\cdot$ national culture

\section{Zoltán Krajcsák}

Department of Management and Corporate Economics, Budapest University of Technology and Economics, Magyar tudósok körútja 2.,Budapest, H-1117, Hungary

e-mail:krajcsak@mvt.bme.hu

\section{Irén Gyökér}

Department of Management and Corporate Economics, Budapest University of Technology and Economics, Magyar tudósok körútja 2.,Budapest, H-1117, Hungary

e-mail: gyoker@mvt.bme.hu

\section{Introduction}

There are many approaches [8] that try to identify when certain types of behavior or attitudes can be defined as job commitment. This is an important question since these days we are still influenced by the consequences of economic crisis both individually and in our macro-environment. In our rapidly changing world recognizing the importance of commitment is a crucial issue for organizations. We could argue that inequality between employees and employers becomes even more apparent in crisis situations, companies taking more advantage of human resources due to the vulnerability of their employees while putting less emphasis on employee satisfaction, ongoing training, career planning systems or performance based and motivating compensation systems. These are all factors that have considerable influence on employee turnover on the labor market during its near-equilibrium state. Large-scale turnover is costly for organizations: they need to advertise for vacant positions (or make use of the services of employment agencies) and to choose the potentially best candidate out of all the applicants, often in complicated selection process, applying many rounds of interviews. Furthermore, even for a new employee who is in possession of the required competence and experience it takes a few months to familiarize with the company's working environment, procedures, culture and ethic, to be able to apply all the methods and procedures in practice with confidence [4]. Of course, this is expensive. On the other hand, representatives of the competitive sector are convinced that utilization of human resources (more than financial or physical goods) their efficiency is the key factor in order to maintain or increase competitive advantage even in times of recession, therefore it needs to be managed on a strategic level. In the long term increasing employee satisfaction and commitment, as well as managing talent will contribute to more beneficial investment into human resources. This study intends to identify the way to achieve job satisfaction and commitment by reviewing significant models and research results.

\section{The development of commitment models}

According to some definitions commitment [8] might be described as the relative strength of organizational involvement 
or a psychological attachment towards the organization or a psychological state that ties the individual to the organization. The concept of motivation and the increase of individual performance don't appear in these definitions so it's necessary to explore the components of commitment. One of the first models [11] describes commitment as a factor which strength is defined by costs of losing organizational membership (Side-bet Theory). In the beginning of the 60's Becker believed that high costs of losing organizational membership comprises groups of workplace cultural expectations, personal relationships, the individual's attitude towards social situations, 'bureaucratic agreements' and self-realization anxiety. The more of these groups are active at the same time, the stronger the individual's connection to the organization will become [8].

The question arises of course, as to what's more important from the point of the company: the individual's attachment to the organization (e.g. due to high costs of losing organizational membership, since the employee won't be able to or will struggle to achieve the same attitude elsewhere) or their commitment to occupation. In the latter case, it's quite likely that only a few factors will connect the employee to the company, therefore they could carry out similar work for the competition as well. In the 70's Porter and Mowday examined commitment from a different angle. They claim that commitment is primarily affective, being influenced by three components: complete identification with organizational culture (acceptance of its goals and values), strong willingness to work for the organization, and desire to remain part of the organization. Based on their research outcomes, Porter and Mowday were the first ones to prove the inverse relationship between commitment and turnover [8] [18]. They assumed that satisfaction forms the basis of commitment; therefore commitment has stronger influence on employment migration than employee satisfaction since it's based on intensive emotions. This is all true with regards to their theory but they couldn't know about later research result, that has shown the commitment is a three-dimensional concept, emotions (affiliation) being only one of the components.

It was essential for them to separate commitment from motivation since emotional attachment doesn't necessarily manifest itself in better quality work or increase in performance although both are beneficial for the company. Research into this field lead to significant changes in the 80's. According to Scholl [14], commitment is influenced by high costs of losing organizational membership (i.e. all the efforts the employee has made so far for the company, which would make it 'too costly' to simply quit), reciprocity (the extent of the individual's 'debt' towards the company) lack of alternatives and social identity. He examined the link between motivation and commitment and came to the conclusion that the connection is not obvious. It is possible that some individual's motivation is lower but their commitment is higher: they might feel that they are treated unfairly compared to their co-workers in terms of the extent of input/output but one (or more) of the above mentioned four reasons ties them to the company. For that matter, its inverse is just as likely, i.e. high motivation but low commitment. In this case extrinsic motivation plays a crucial role, e.g. the employee remains with the company because it's worthwhile ('they don't pay this well elsewhere').

Angle and Perry distinguish between types of commitment in their studies. According to them, commitment comprises of value commitment and continuance commitment. The former measures the extent to which employees are willing to accept and identify with the goals of the company, the latter the extent of maintaining institutional membership. They found that there's no correlation between continuance commitment and individual performance, and that value commitment has a positive influence primarily on the quality of work [8]. The authors' probably most interesting statement is that there's no connection between commitment and organizational success. However, Allen and Meyer are the only ones so far who have given an explanation for this [10].

Based on the analysis of the above mentioned theories Allen and Meyer described commitment as a three-dimensional model. They identified the components of commitment, examined their correlations and carried out a research with regards to what human resource management practices correlate with certain types of commitment. Basically they tried to find out how to improve commitment, with more or less success. According to their model, commitment is influenced by the following factors:

- affective commitment, which reflects our willingness to act on behalf of the organization, our identification with the values and goals of the organization and our desire to remain part of the organization in the future;

- continuance commitment (perceived costs), which is shaped by two factors:

- commitment deriving from the lack of alternatives

- personal sacrifice (work relationships and friendship ties);

- normative commitment, when the employee remains with the organization because of feelings of obligation for some reason or other.

Based on their research outcomes [10] and using statistics from research carried out with high scientific standards, new statements have been made. Such as: there is a strong negative correlation between affective commitment and perceived costs associated with leaving the organization but at the same time, there's no correlation between continuance commitment and turnover. In 1995 Somers [15] pointed out that continuance commitment strengthens affective commitment, therefore indirectly it influences the willingness to remain with the company and the decrease in absenteeism. Later research proposes that only the second component of continuance commitment (value of personal sacrifice) is in negative correlation with job withdrawal intentions. Until recently nobody has been able to prove whether satisfaction is the basis of commitment or rather it's 
consequence. In his research in 2000 Currivan was trying to find the connection between affective commitment and satisfaction but he couldn't prove the correlation between the two components either [8]. I'd like to use the model developed by Allen and Meyer during further research, as based on the above, it matches the definition of commitment to the greatest extent. According to our present knowledge, the three-dimensional model defines the complicated process of the development of commitment attitude in the most complex way. Tab. 1. presents the comparative analyses of the most significant commitment theories.

\section{The relationship between motivation and commit- ment}

While trying to define commitment, we might come across explanations that differ in their content. It seems logical that we relay on a concept that motivation should play part of, although this is not necessarily true, even though in most cases commitment appears to have connection to intrinsic motivation. Intrinsic motivation influences our attitude to work, e.g. as we want to work harder and better at our workplace, or to work more because we want to do it for the sake of the job itself, we wish to be acknowledged, or to become experts, to assume higher level responsibility, and last but not least, we like to be challenged.

The classic example for explaining how intrinsic motivation works, is Herzberg's two-factor theory. It makes some significant statements, even though according to its critique it is more of an attitude study rather than motivation theory, since the author didn't even examine the extent of individual performance (in which the motivation is manifested) in his survey that gives the basis of the theory. Herzberg's theory distinguishes between the satisfactions and dissatisfactions, as a consequence satisfaction and dissatisfaction are not the ends of a single bipolar scale, as both are being influenced by different factors. The so called motivator factors are essential to ensure employee satisfaction, while the absence of so called hygiene factors (salary, work conditions, personal relations) results in dissatisfaction [5]. In the classic context of commitment job satisfaction is considered being granted otherwise the employee would only show positive attitude towards hygiene factors which according Herzberg's theory have no influence on motivation. In turn motivation plays an essential role in commitment since the increase of performance is the goal. Fig. 1 presents the correlation between satisfaction and dissatisfaction.

Extrinsic motivation contributes nothing or very little to commitment, as the employee makes an effort only in order to attain specific extrinsic outcomes, rewards. His motivation only lasts as long as the target has been reached. On the other hand, intrinsic motivation and commitment generate new goals all the time.

\section{The role of commitment influencing factors}

Every organization and each manager is wishing to have committed employees. There are several management methods to
Traditional view

Satisfaction

Dissatisfaction

\begin{tabular}{ll}
\multicolumn{2}{c}{ Herzberg's Two-Factor Theory } \\
Motivators & No satisfaction \\
Satisfaction & \\
\multicolumn{2}{c}{ Hygiene Factors } \\
No dissatisfaction & Dissatisfaction
\end{tabular}

Fig. 1. Herzberg's two-factor theory

increase commitment now we are going to point out some of the most significant ones.

The improvement of Leader-Member Exchange (LMX) can be the first obvious solution. LMX describes the quality of the relationship between supervisors and subordinates. Some management thinkers [18] believe that the typical employee of the $21^{\text {st }}$ century is going to work according to a different workschedule compared to those before. It is necessary to deal with this issue since alternative and more flexible solutions will gain significance eliminating physical barriers in work arrangements. In the future most employees won't be tied by space and time, and due to IT innovations (factors, like enterprise resource planning, mobilization, telecommunicating) the traditional 8-hours office workday will become a thing of the past. Depending on their possibilities and goods, employees will be able to work virtually having the choice of place and time. It would be worthwhile to examine how the extent of LMX influences the commitment of those working in virtual space. Research results prove that LMX is more determining for people doing virtual work than those working in traditional employment arrangement (3). Low LMX weakens employee commitment considerably while higher LMX strengthens it considerably if a significant amount of their work is done in telework, i.e. away from an office. The reason might be that during this type of work the employer has to have more trust in the employee who, therefore can handle more challenges since there is less supervision. However, the personality of the employee is a determining factor as well. This is all based on the Social Exchange Theory which proposes that the quality of the LMX relationship is improved by the exchange of material and non-material gains. It examines human relationships according to their direct and obvious benefits claiming that individuals take part in transactions that they can profit from, and relationships only last as long as partners are able to provide each other with valuable goods. There are many such resources: love, social status, information, money, goods and services. Relationships often begin with the exchange of universal personal resources (e.g. goods and services), close relationships however are characterized by symbolic and particular exchanges (e.g. emotional manifestations) where the parties' identity is also important. Although earlier theories considered 
Tab. 1. Comparative analyses of the most significant commitment theories

\begin{tabular}{|c|c|c|c|c|}
\hline Researchers & & $\begin{array}{l}\text { Number and interpretation of the di- } \\
\text { mensions of commitment }\end{array}$ & Factors influencing commitment & $\begin{array}{l}\text { The most significant results of the } \\
\text { theory }\end{array}$ \\
\hline Becker & 1 & $\begin{array}{l}\text { Commitment is defined by the degree of } \\
\text { loss }\end{array}$ & $\begin{array}{l}\text { Cultural expectations, personal relation- } \\
\text { ship, social connections, bureaucratic } \\
\text { agreements }\end{array}$ & $\begin{array}{l}\text { The more influencing factors are active } \\
\text { at the same time, the stronger the com- } \\
\text { mitment }\end{array}$ \\
\hline $\begin{array}{l}\text { Porter } \\
\text { \& Mowday }\end{array}$ & 1 & Commitment is emotionally motivated & $\begin{array}{l}\text { Identification with the organizational cul- } \\
\text { ture, strong inclination to implement the } \\
\text { goals of the organization, strong desire } \\
\text { to maintain organizational membership }\end{array}$ & $\begin{array}{l}\text { Commitment has stronger influence on } \\
\text { fluctuation than satisfaction, as it as- } \\
\text { sumes more intense emotions. }\end{array}$ \\
\hline Scholl & 1 & $\begin{array}{l}\text { Commitment can change the behavior ir- } \\
\text { respective of motivation. }\end{array}$ & $\begin{array}{l}\text { Loss, reciprocity, lack of alternatives, } \\
\text { identification }\end{array}$ & $\begin{array}{l}\text { Committed behavior can occur even } \\
\text { when expectation or fairness criteria are } \\
\text { not granted }\end{array}$ \\
\hline Perry \& Angle & 2 & $\begin{array}{l}\text { Commitment is defined by the ratio } \\
\text { of value commitment and continuance } \\
\text { commitment. }\end{array}$ & $\begin{array}{l}\text { Acceptance of organizational goals, de- } \\
\text { sire to maintain organizational member- } \\
\text { ship }\end{array}$ & $\begin{array}{l}\text { There is no obvious correlation between } \\
\text { commitment of employees and success }\end{array}$ \\
\hline Meyer \& Allen & 3 & $\begin{array}{l}\text { Committed attitude is made up of } \\
\text { affective-, continuance- and normative } \\
\text { commitment. }\end{array}$ & $\begin{array}{l}\text { Emotional attachment to the organiza- } \\
\text { tion, perceived costs of leaving the orga- } \\
\text { nization, sense of duty towards the work } \\
\text { in the organization }\end{array}$ & $\begin{array}{l}\text { There is a strong negative correlation } \\
\text { between affective commitment and the } \\
\text { desire to remain part of the organization } \\
\text { but there is no correlation between con- } \\
\text { tinuance commitment and fluctuation. }\end{array}$ \\
\hline
\end{tabular}

goods interchangeable, others believe that certain types of goods can only be exchanged for the same types, e.g. money can't buy love. The cohesion of relationships depends on both the reciprocal exchange of costs and benefits, and the personal experience of the individuals' alternatives. While forming relationships exchanges become more frequent, more diverse and riskier, and the short-term absence of reciprocity will be tolerated more by close and long-term relationships. According to the theory, emotional attachment will form between the employee and employer after a while, and the acceptance of material and non-material gains will assume compensation. Virtual work increases the gap between supervisors and subordinates, and to overcome it successfully depends on its extent. Virtual work changes the sense of responsibility towards the reciprocity of exchange: the more the individual is allowed to work virtually, the stronger this sense becomes.

It's indisputable that there is a strong correlation between a high LMX value and job satisfaction, but based on the above, telework only increases the normative factor of commitment.

Examinations have found [9] that parallel to age, the correlation between quality of work (expertise and skill) and positive work attitudes gets stronger, while correlation between attitudes and the extent of individual development shows a weakening tendency. Conway and Finegold [2] examined the correlation between commitment and life and career stages, and found that demands of employees, benefits of HR practices and work attitudes change with age. Based on these findings the authors of the article assume that associations between HR practices and work-related attitudes change with age as well. The effects of the HPWP (High Performance Work Practices) index on organizational performance have been proved in many publications. It improves teamwork, results in lower turnover and increases desire for development. However, the negative effects of HPWP on the individual haven't been explored to the full extent. Responsibility grows, the work -life balance is disturbed, stress increases, which diminishes commitment in the long term [9]. Sparham and Sung found that during permanent HPWP the negative effects mentioned above significantly reduce its advantages and only work becomes more intensive. However, some researchers [12] believe that improved job satisfaction attitudes reduce the negative effects.

Organizational culture (values, beliefs, attitudes, habits of the organization), which also has an effect on the commitment of individuals cannot be changed from one moment to another, since it takes long time to understand and internalized by the member of the organization. The culture is shaped by its founders' and leaders' way of thinking and their expected and practiced behavior norms. At the same time though, the organizational culture is influenced by national culture, the characteristics of which reflect by the behavior of average companies in that region or country. Several researches examined the effect of the features of national cultures on employee commitment. The Hofstede Model which defines four dimensions of national culture is a well-known one.

Research has proved [6] that strong individualist phenomena (e.g. Western-Europe) have a negative influence on commitment, since individuals are more conscientious and selfsacrificing in a collectivist society, and they have a sense of belonging to the inner group of the organization. If the Power Distance Index (PDI) is high (the manager's position is more important than their activity), the continuance and affective commitment is lower than in case of a lower Power Distance Index. 
However, there's no correlation between the PDI and normative commitment. Where the Uncertainty Avoidance Index (UAI) is high, employees usually demonstrate a higher commitment value against all three Meyer-Allen dimensions. Again, no correlation has been found so far between the extent of commitment types and level of masculinity (MAS).

In the introduction of this study we have emphasized the significance of commitment. In our changing economy the proportion of jobs requiring strong commitment or corresponding behavior has increased while factors traditionally responsible for commitment have diminished. Current studies analyzing this topic mention the so called 'commitment gap' and surveys often referred to in these articles point out that employers of the new economy are worried about the loyalty of their employees. Some claim that there's no need for commitment in economy as such, as organizational and employment restructuring brought about 'boundaryless careers' and a new type, the profession-oriented employee. Conversely, others say that despite these changes commitment has never been this important. The new economy is based on knowledge- and service-centered companies, who, similarly to high-performance factory workers need to be able to demonstrate organizational commitment. Employees have positions requiring extensive clientele, high levels of discretion and decision making responsibility, which are circumstances that emphasize the importance of organizational commitment [13]. Necessary participation of employees contributes to high-commitment work. High commitment workplaces and normative forms of leadership apply various approaches to ensure that employee actions reflect organizational interest as if their goals were identical to those of the organization. This is in contrast with the technical and bureaucratic control systems applied to a great degree in some fields of the economy of the $20^{\text {th }}$ century. These changes are reflected in different forms currently in the economy: e.g. in the manufacturing industry of Western countries employees are expected to be in possession of cognitive abilities, they are provided with ongoing training, and 'high commitment strategies' are used in order to achieve the desired attitude. Instead of waiting for mobility opportunities while climbing the career ladder, employees exchange their security expectations for gaining new knowledge, personal development and 'continuous ability to work'. High commitment workplaces often provide their distinguished employees with certain degree of security.

Organizational Citizenship Behavior (OCB) might play a significant role in this respect. Researchers haven't been able to find any correlation between high level commitment and employee performance. According to assumptions, excess effort due to committed attitude manifests itself in voluntary work rather than better performance of expectations (faster, better quality work) outlined in job descriptions.

Perceived Organizational Support (POS), which reflects employees' perception of the extent to which the organization values their work and cares about their well-being plays a crucial role in this. The POS indicates how safe, positive and caring the workplace is according to the employee (1). Therefore companies need to aim to provide such environments as this motivates employees to make the extra effort to accomplish tasks beyond their role. Perceived Organizational Support also reflects the attitude of leadership towards employees. POS affects employees' desire for relationships thus it becomes one of the most important factors to impact affective commitment [18]. If POS is high employees feel that they are obliged to 'repay' the favours to the organization [17]. Since POS and affective commitment can be considered as social exchange relationships, POS has no impact on the other two dimensions of commitment. Therefore, POS is connected exclusively and positively to affective organizational commitment. Similarly, LMX also connects to affective commitment exclusively and positively, since it primarily reflects the emotional relationship towards the leader, and not the attitude towards the organization. However, Perceived Team Support (PTS), which indicates employees' satisfaction with their colleagues is probably even more significant than the above mentioned indices. It's been scientifically proved that affective commitment has the strongest positive correlation with PTS [18].

In this article we've introduced the most significant research results regarding commitment that are available in international scientific literature. It would also be interesting to examine how workforce hire relates to commitment. Nowadays many shortterm workforces are necessary because of the changing economic situation. It is normally required for seasonal or casual jobs and is regarded as secondary by employers and employees alike. However, organizations do not necessarily need to renounce committed workforce in favour of hired ones. Hired workers whose services are only available for up to a year are aware that they don't belong to the 'inner circle' of the organization. Their work is only temporary and during downsizing they are the first ones to leave. Despite all this, their loyalty can be encouraged by legal rules and management actions, such as drawing up career plans for them as well. Kartyas [7] emphasizes that it's possible to boost work by appropriate wage systems (e.g. hiring parties requite extra performance via lending parties) but as described above, this solution is only temporary and influences extrinsic motivation rather than commitment. Another solution for hiring companies would be to offer their employees the opportunity to move up the career ladder by rewarding the best performers with indefinite employment contracts (called the springboard of hire), which could be considered as trial period. Hiring companies haven't carried out any comprehensive studies so far though that would prove return on investment into increasing the commitment of short term hired workforce.

\section{Final thoughts}

Despite the conclusions of the models described above, practicing HR people normally refer to two simple solutions by as- 
suming that the only measurable component of commitment is performance, the improvement of which can be achieved by short-term measures. An example of such solutions is the restructuring of payment systems or applying measures that lead to and maintain commitment. Payment systems used by most companies in the competitive sector consist of a personal base rate and performance-related pay. It is quite common that companies offer a considerably low basic wage that is then supplemented by performance related pay. Based on research outcome [16] performance related pay itself doesn't act as motivator while personal base rate plays a more crucial role but if it's low, employees become demotivated. What concerns satisfaction, it's not clear whether it forms the basis or consequence of commitment, neither whether it's a micro-concept that leads to the macro-concept of commitment.

In our study, we've looked at the evolution of the concept and definition of commitment, and also touched on its role in relation to motivation, fluctuation and satisfaction. The models that differ from each other significantly have channeled our research on commitment in different directions, and although we have been given exciting answers to some details, the most important global questions remain unanswered so far. There is a need for further research to find out what other workplace factors could influence commitment apart from the already introduced ones, to identify a more accurate definition for the correlation between the concepts of commitment and satisfaction, and furthermore, to determine the correlation between the motivation strategies, motivated behavior, commitment and performance of employees working in certain sectors of the service industry.

\section{References}

1 Connelly CE, Gallagher DG, Gilley KM, Organizational and client commitment among contracted employees: A replication and extension with temporary workers, Journal of Vocational Behavior, 70(2), (2007), 326-335, DOI 10.1016/j.jvb.2006.10.003.

2 Conway E, Relating career stage to attitudes towards HR practices and commitment: Evidence of interaction effects?, European Journal of Work and Organizational Psychology, 4(13), (2004), 417-446, DOI 10.1080/13594320444000155.

3 Golden TD, Veiga JF, The impact of superior-subordinate relationships on the commitment, job satisfaction, and performance of virtual workers, The Leadership Quarterly, 19(1), (2008), 77-88, DOI 10.1016/j.leaqua.2007.12.009.

4 Gyökér I, Krajcsák Z, Az alkalmazotti elégedettséget és elkötelezettséget befolyásoló tényezók vizsgálata, (Analyzing factors influencing employee satisfaction and commitment), Vezetéstudomány, 40/különszám, (2009), 56-61.

5 Herzberg F, Még egyszer: Miként motiválja alkalmazottait?, (One more time: How do you motivate employees?), Harvard Business Manager, 5/6, (2003), 38-48.

6 Jaramillo F, Mulki JP, Marshall GW, A meta-analysis of the relationship between organizational commitment and salesperson job performance: 25 years of research, Journal of Business Research, 58(6), (2005), 705-714, DOI 10.1016/j.jbusres.2003.10.004.

7 Kártyás G, A kölcsönbe vett lojalitás, (The borrowed loyalty), Munkaügyi Szemle, 54(2), (2010), 42-46.
8 Kiss C, A szervezeti elkötelezettség elméletei, (Theories of organizational commitment), Munkaügyi Szemle, 54(2), (2010), 14-23.

9 Koolij DTAM, Jansen PGW, Dikkers JSE, De Lange AH, The influence of age on the associations between HR practices and both affective commitment and job satisfaction: A meta-analysis, Journal of Organizational Behavior, 31(8), (2010), 1111-1136, DOI 10.1002/job.666.

10 Meyer JP, Stanley DJ, Herscovitch L, Topolnytsky L, Affective, Continuance, and Normative Commitment to the Organization: A Meta-Analysis, Correlates, and Consequences, Journal of Vocational Behavior, 61(1), (2002), 20-52, DOI 10.1006/jvbe.2001.1842.

11 Powell DM, Meyer JP, Side-bet theory and the three-component model of organizational commitment, Journal of Vocational Behavior, 65(1), (2004), 157-177, DOI 10.1016/S0001-8791(03)00050-2.

12 Rod M, Ashill NJ, The relationship between job demand stressors, service recovery performance and job outcomes in a state-owned enterprise, Journal of Retailing and Consumer Services, 15(1), (2008), 22-31, DOI 10.1016/j.jretconser.2007.02.002.

13 Rubin BA, Brody CJ, Contradictions of commitment in new economy: Insecurity, time, and technology, Social Science Research, 34(4), (2005), 843861, DOI 10.1016/j.ssresearch.2005.02.002.

14 Scholl RW, Differentiating Organizational Commitment from Expectancy as a Motivating Force, The Academy of Management Review, 6(4), (1981), 589-599, DOI 10.2307/257637.

15 Somers M, Organizational Commitment, Turnover and Absenteeism: An Examination of Direct and Interaction Effects, Journal of Organizational Behavior, 16(1), (1995), 49-58, DOI 10.1002/job.4030160107.

16 Szénási EL, A személyi alapbér és a teljesítmény kapcsolata, (The relationship between basic wage and performance), Munkaügyi Szemle, 52(2), (2008), 50-52.

17 Treadway DC, Hochwarter WA, Ferris GR, Kacmar CJ, Douglas C, Ammeter AP, Buckley MR, Leader political skill and employee reactions, The Leadership Quarterly, 15(4), (2004), 493-513, DOI 10.1016/j.leaqua.2004.05.004.

18 Vandenberghe $\mathbf{C}$, Bentein $\mathbf{K}$, Affective commitment to the organization, supervisor, and work group: Antecedents and outcomes, Journal of Vocational Behavior, 64(1), (2004), 47-71, DOI 10.1016/S0001-8791(03)00029-0. 